\title{
EFFECT OF TEMPERATURE AND SALINITY ON HEAT TOLERANCE. IN TWO GRAPSOID CRABS, HEMIGRAPSUS NUDUS AND HEMIGRAPSUS OREGONENSIS ${ }^{1}$
}

\author{
MARY-ELIZABETH TODD ${ }^{2}$ AND PAUL A. DEHNEL
}

Department of Zoology, University of British Columbia, Vancouver, British Columbia, Canada

Temperature tolerance as an experimental criterion for the demonstration of physiological change has found many uses and has been reported in various ways throughout the literature. Most studies on temperature tolerance have been done on fish, with relatively few experiments on invertebrates. In many cases the lethal point was determined by the temperature at which death occurred when the animal was subjected to slowly increasing temperatures (Huntsman and Sparks, 1924; Gowanloch and Hayes, 1926). As various authors raised the temperature at differing rates, the results could not be compared adequately because the time over which the temperature was increased would be expected to have a marked effect on the final lethal point. Experiments in which animals were maintained at constant temperatures for a period of time provided a more accurate determination of the lethal temperature as well as allowing comparisons among the species. In this type of experiment, either time to death or per cent survival at intervals was noted (Fry, Brett and Clawson, 1942; Brett, 1952; Spoor, 1955).

Acclimation to low and high temperatures has been demonstrated in many animals on the basis of laboratory acclimation, season, microgeography and latitude. In this discussion, "acclimation" includes all types of "demonstrable compensatory change" (Bullock, 1955). Acclimation has been demonstrated by a higher rate function at any intermediate temperature when low temperature acclimated animals are compared with high acclimated ones. Dehnel and Segal (1956) in laboratory studies on the American cockroach, Periplaneta americana, found a higher rate of oxygen consumption in equal-weight nymphs and adults after acclimation to $10^{\circ} \mathrm{C}$. when compared with $26^{\circ} \mathrm{C}$. acclimated animals. Respiration was measured at $20^{\circ} \mathrm{C}$. Previously, the culture had been maintained for at least three generations at a constant temperature, $27^{\circ}$ C. Edwards and Irving (1943) showed seasonal acclimation in the sand crab, Emerita talpoida. At all experimental temperatures below $20^{\circ} \mathrm{C}$., oxygen consumption of animals in summer was less than that in winter. Ohsawa and Tsukuda (1956) found seasonal acclimation of response to temperature (exuding of the body) in the periwinkle, Nodilittorina granularis. Microgeographical acclimation has been demonstrated in the limpet, Acmaea limatula. Samples taken from lower intertidal levels had a higher rate of heart beat than those from higher levels (Segal, 1956).

${ }_{1}^{1}$ These studies were aided by grants from the National Research Council of Canada and the National Science Foundation of the United States. The authors wish to express their gratitude to Dr. Earl Segal and Dr. Theodore H. Bullock for their critical reading of the manuscript.

2 Present address : Department of Zoology, University of Glasgow, Glasgow W. 2, Scotland. 
Mayer (1914) has shown that at different latitudes there was a similar rate function within a species at the environmental temperatures of the individuals, even though these temperatures were different. The rate of pulsations of the bell of Aurelia aurita was similar in animals off Nova Scotia and off Florida with a temperature difference of $15^{\circ} \mathrm{C}$. Scholander, Flagg, Walters and Irving (1953) compared many poikilotherms, mostly interspecific but closely related species, from arctic and tropic regions to find the general consistency of acclimation when rates of oxygen consumption were investigated. Dehnel (1955) demonstrated a higher rate of growth in gastropods from high latitudes when compared with low latitude populations.

Another facet of acclimation is its effect on the temperature tolerance of a species. A previous temperature history at the upper levels of the physiological temperature range is known to raise the thermal resistance. Conversely, low temperature acclimation will decrease the tolerance to high temperatures. The rates of gain and loss of heat tolerance appeared to show a consistent trend in diverse groups of animals. In all cases, gain of heat tolerance was much more rapid than its loss. Brett (1946) demonstrated that the goldfish, Carassius auratus, required a total of thirty days to acclimate to $28^{\circ} \mathrm{C}$. when brought from $4^{\circ} \mathrm{C}$. in $8^{\circ} \mathrm{C}$. steps, but that acclimation occurred at different rates. Twenty days were required from $4^{\circ} \mathrm{C}$. to $12^{\circ} \mathrm{C}$., but only three days from $20^{\circ} \mathrm{C}$. to $28^{\circ} \mathrm{C}$. Loss of heat tolerance in the crayfish, Orconectes rusiticus, was not completed by the end of the sixteenth day when the crayfish were transferred from $22^{\circ}-23^{\circ}$ C. to $4^{\circ} \mathrm{C}$. The heat tolerance lost after thirteen days at $4^{\circ} \mathrm{C}$. was regained in about 24 hours (Spoor, 1955). Ohsawa (1956a) using the periwinkle Nodilittorina granularis, stated (p. 206), "The acclimatization to higher temperatures in the winter snails is established more readily than the acclimatization to lower temperatures in the summer animals."

The effects of salinity changes on temperature tolerance have been studied less extensively. Broekema (1941) demonstrated that the temperature and salinity relations were interdependent in the shrimp Crangon crangon when survival in various combinations of the two was tested; a low salinity was endured better when the temperature was high. Wikgren (1953) showed that there was almost a continuous loss of ions from the crayfish, Potamobius fluviatilis, as the temperature dropped below $2^{\circ} \mathrm{C}$. from about $18^{\circ} \mathrm{C}$. when animals were transferred from tap to distilled water. There was apparently more efficient osmoregulation, normal loss of ions, at higher temperatures (above $2^{\circ}-3^{\circ}$ C.). The lobster, Homarus americanus, was shown to have a higher lethal point when both salinity and temperature were high during the period of acclimation. A decrease in salinity with the acclimation temperature held constant resulted in a lowering of thermal resistance (McLeese, 1956).

The two species of shore crabs studied in this investigation, Hemigrapsus nudus (Dana) and $H$. oregonensis (Dana), are subjected to wide ranges of temperature and salinity conditions in their natural environment. Experimental parameters of temperature and salinity were based on average seasonal conditions, to determine if these seasonal changes, summer and winter, cause a resulting change in the upper temperature tolerance of the two species. Also, animals were acclimated to various combinations of temperature and salinity, to ascertain any resulting changes in 
the temperature tolerance within either season. Because of the morphological similarity and like habitat in this area of these two species, it was hoped that physiological differences, in this case resistance to high temperatures, could be demonstrated. This was found to be the case. Additionally, effects of size, crowding, sex and moulting on the tolerance were noted.

\section{Material and Methods}

The experimental animals, $H$. nudus and $H$. oregonensis, were collected from Spanish Bank Beach on the south shore of Burrard Inlet. The Fraser River flowing into Georgia Strait near the collecting beach is the main cause of the recorded fluctuations in salinity occurring in this area. The beach has a gradual slope and changes its contour from sand to rocks and again to sand. The lower sandy area is exposed only on the lower tides. The crabs are found in the rocky intermediate area, the main population of $H$. nudus distributed higher than that of $H$. oregonensis. Individuals of both species, however, can be found almost from highest occurrence to lowest.

The salinity is quite uniform throughout the winter, ranging from about 70 per cent to 80 per cent sea water (based on 100 per cent sea water as $31.88 \%$ ). In the spring, with the greater influx of fresh water from the Fraser River, the salinity begins to drop and has been recorded as low as 10 per cent in the summer months. At the same time as the salinity is decreasing, temperature increases, and the relatively static summer state results where the average salinity is about 35 per cent. Daily fluctuations in the salinity also occur, as the incoming tide carries a less saline water along the shore in the collecting region. This muddier Fraser River water is distinct from the water of higher salinity by a visual demarcation several hundred yards from shore.

The two species of crabs are found under rocks where a suitable micro-environment is provided by a pool of water or a bed of mussel shells (Mytilus edulis). Both species are found also in damp sand under rocks, often partially buried. Both males and females were used in the temperature tolerance experiments when preliminary experiments showed no difference in the resistance of the sexes. Gravid females or individuals missing any appendages were discarded, as were any softshell crabs. A weight range was collected, about $0.2 \mathrm{gm}$. to $6.0-\mathrm{gm}$. animals, excluding only very large individuals. Crabs were transported to the laboratory in canvas buckets with damp sea-weed. The experiments reported here were conducted from 1957 to 1959, inclusive.

In this investigation, holding experiments refer to those in which the temperature tolerance of the crabs is determined without any previous laboratory acclimation. The animals were tested after at least 24 hours in the laboratory, and during that period they were held at temperature and salinity conditions which approximated those in the field. This time period allowed the gut to be cleared partially so that at the high test tolerance temperatures, deposition of faeces and urine did not foul the water. In acclimation experiments, on the other hand, animals were held at previously determined acclimation conditions which differed from environmental circumstances in at least one factor. In these experiments crabs were acclimated for at least one week in the laboratory. Preliminary experiments indi- 
cated that acclimation was complete in less than seven days; the tolerance of the two species, therefore, was tested from seven to a maximum of twenty-one days in some experiments. Crabs were not fed at any time during the experiments, and were kept in darkness.

If the acclimation temperature differed greatly from the environmental temperature, the crabs were gradually warmed or cooled until the desired temperature was reached, usually a period of two hours. Plastic dishes containing slightly less than 4 liters of water were used for the experimental animals. Holding or acclimation temperatures were either $5^{\circ} \mathrm{C}$. or $20^{\circ} \mathrm{C}$., $\pm 1^{\circ} \mathrm{C}$., based on average winter and summer temperatures. The salinities were either 75 per cent or 35 per cent sea water, again average seasonal conditions. Hence, four experimental combinations were used. About thirty-five crabs were placed in each container. Animals were changed, usually once per 24 hours, to water of appropriate temperature and salinity over the acclimation or holding period.

Temperature tolerance tests were conducted by floating the plastic containers in water baths in which the experimental temperature did not vary more than $\pm 0.1^{\circ} \mathrm{C}$. The appropriate salinity, corresponding to that used during the acclimation or holding period, was employed for each tolerance test. Five animals per dish (per 4 liters of water) were tested at $1^{\circ} \mathrm{C}$. intervals, from $28^{\circ} \mathrm{C}$. to $35^{\circ} \mathrm{C}$. The five crabs tested at each temperature ranged in weight from small to large. At each temperature both males and females were tested. Crabs were brought to the test temperature from acclimation or holding temperatures over a period of two to four hours at which time the experiment was begun. Preliminary experiments indicated that more time was unnecessary as a more gradual warming period did not alter the results. The experiment was conducted for 24 hours; dead animals were removed at 12 hours and live ones were changed to clean water. All animals were dried with gauze and weighed to the nearest $0.1 \mathrm{gram}$. Animals were considered dead only when all movement ceased. Using this criterion as a death point, at no time did animals revive when returned to lower temperatures. Immediately prior to death, the sole motion visible was a slight pumping of water through the gill chambers. Crabs which moulted during the 24 hours of the experiment were discarded.

The relationship of weight and time to death was determined by checking at hourly intervals over the 24-hour period and removing and weighing any dead animals. There was a change of water at 12 hours as noted previously. One set of experiments was used to test the effect of different numbers of crabs per dish on the thermal resistance. All experimental conditions were as described in the foregoing except for the varying densities of animals at each test temperature.

Data were plotted on arithmetic paper as it was believed that this type of plot gave the most accurate representation of the temperature tolerance curve. Each point, indicating per cent survival at any given temperature, represented the average of a number of duplications (each five animals per dish) for those particular conditions. In no instance was this average determined from less than six replications resulting in a total of at least thirty animals; usually more were used. The total graph, then, was based on a minimum of one hundred-eighty animals. No attempt was made to derive a formula for the fitting of each curve; the points were merely joined. The 50 per cent survival temperature was based on the 
point at which the survival curve crossed the line representing median survival of the animals. In the graph which represented the relationship between size and time to death, the regression line is eye-fitted.

An analysis of variance was done for the complete summer data mainly to determine if a species difference existed. The difference in tolerance between the species was less during the summer months, so that a significant difference here definitely indicated one for the complete data, both summer and winter. For individual comparisons such as the difference in tolerance between the species at a given temperature-salinity combination, the "Student's" $t$-distribution was used to compare the 50 per cent survival temperatures. Another method was the comparison of the total area under the curve for any two graphs, contrasting the total cumulative per cent survival. The statistical probabilities resulting from the $t$ test using this method were approximately the same as when 50 per cent survival temperatures were compared. Since the latter is a value commonly found in the literature, this was chosen as a basis for comparison rather than the total cumulative survival value. In all cases where a statistically significant difference has been demonstrated using the $t$ test, the level of significance is based upon the 0.05 probability point, although the probability in some instances is less than the 0.01 level.

\section{Results}

SUMMER

Average conditions of salinity and temperature representing the summer months were $20^{\circ}$ C. and 35 per cent sea water. Survival values obtained from summer animals with no laboratory acclimation, holding experiments, were considered as the base line curves. These curves were compared with heat tolerances of animals acclimated to $20^{\circ}$ C., 75 per cent sea water; $5^{\circ}$ C., 35 per cent sea water; and $5^{\circ}$ C., 75 per cent sea water. Temperatures at which 50 per cent survival occurred for 12 and 24 hours were used as the basis for comparisons.

\section{Holding Experiment: $20^{\circ}$ C. and 35 per cent sea water}

Results of the base line experiments showed that $H$. oregonensis was more resistant than $H$. nudus at both 12 and 24 hours. The temperature at which 50 per cent survival was found for $H$. oregonensis was $33.43^{\circ} \mathrm{C}$. for 12 hours and $33.16^{\circ} \mathrm{C}$. for 24 hours. For $H$. nudus the values were $32.95^{\circ} \mathrm{C}$. for 12 hours and $32.50^{\circ}$ C. for 24 hours (Fig. 1).

\section{Acclimation Experiment: $20^{\circ}$ C. and 75 per cent sea water}

Both species showed a marked increase in tolerance after acclimation to $20^{\circ} \mathrm{C}$. and 75 per cent sea water. This combination of temperature and salinity differed from the base line conditions only in the salinity, having been changed from 35 per cent to 75 per cent sea water. $H$. oregonensis again showed more tolerance than $H$. nudus with values of $34.50^{\circ}$ C. for 12 hours and $34.38^{\circ}$ C. for 24 hours, an increase of $1.07^{\circ} \mathrm{C}$. and $1.22^{\circ} \mathrm{C}$, respestively, over the base line values. The 50 per cent survival temperatures for $H$. nudus were $33.62^{\circ} \mathrm{C}$. and $33.45^{\circ} \mathrm{C}$. for 
12 and 24 hours, an increase of $0.67^{\circ} \mathrm{C}$. and $0.95^{\circ} \mathrm{C}$. (Fig. 2). The increase found in both species was significantly different from the base line values, $\mathrm{P}=.05$. It is important at this point to note that acclimation to the above conditions provided the most favourable background for withstanding the high test tolerance temperatures.

\section{Acclimation Experiment: $5^{\circ}$ C., 35 per cent sea water}

Low temperature and low salinity combined appeared to be slightly less favourable for survival during the acclimation period as the number of deaths in both species was greater than with any of the other combinations, but with fewer deaths among $H$. nudus. Results showed the tolerance to be much the same as the base line values, with no significant difference for 50 per cent survival, $33.28^{\circ} \mathrm{C}$. and $33.11^{\circ} \mathrm{C}$. for $H$. oregonensis and $33.38^{\circ} \mathrm{C}$. and $32.64^{\circ} \mathrm{C}$. for $H$. mudus for 12 and 24 hours (Fig. 3).

Acclimation Experiment: $5^{\circ}$ C., 75 per cent sea water

Acclimation to these conditions did not result in much change in the tolerance when compared with base line conditions. It is possible that the time allowed for acclimation was not of sufficient duration, since animals collected in the winter, when these conditions were found in the field, did show a lowering of the tolerance. However, no change was detected in the temperature at which 50 per cent survival occurred in the summer animals after seven days' acclimation compared with a total of thirteen days' acclimation. The temperatures for 50 per cent survival for $H$. oregonensis were $33.20^{\circ} \mathrm{C}$. and $32.73^{\circ} \mathrm{C}$. and for $H$. nudus, $33.05^{\circ} \mathrm{C}$. and $32.58^{\circ}$ C. for 12 and 24 hours (Fig. 4). These values did not have a significant difference from those found in the base line experiments. When these animals, however, were compared with animals acclimated to $20^{\circ}$ C., 75 per cent sea water (Fig. 2), a significant difference in tolerance was found, $\mathrm{P}=.05$. Summer animals, then, when acclimated to both high and low temperatures with high salinity constant, demonstrated a reduction of thermal tolerance with the low temperature acclimation.

\section{WINTER}

The winter base line represented the heat tolerance of animals collected during the winter months. These were the winter holding experiments. Also, winter animals were acclimated to the three remaining combinations: $20^{\circ} \mathrm{C}$., 35 per cent sea water ; $20^{\circ} \mathrm{C}$., 75 per cent sea water ; and $5^{\circ} \mathrm{C}$., 35 per cent sea water.

\section{Holding Experiment: $5^{\circ} \mathrm{C}$., 75 per cent sea water}

The 50 per cent survival temperatures were $32.59^{\circ} \mathrm{C}$. and $32.43^{\circ} \mathrm{C}$. for $H$. oregonensis and $32.00^{\circ} \mathrm{C}$. and $31.79^{\circ} \mathrm{C}$. for $H$. nudus for 12 and 24 hours, respectively (Fig. 4). The difference between these winter values and those obtained for summer animals acclimated to these same conditions (winter) is significant, $\mathrm{P}=.05$. 


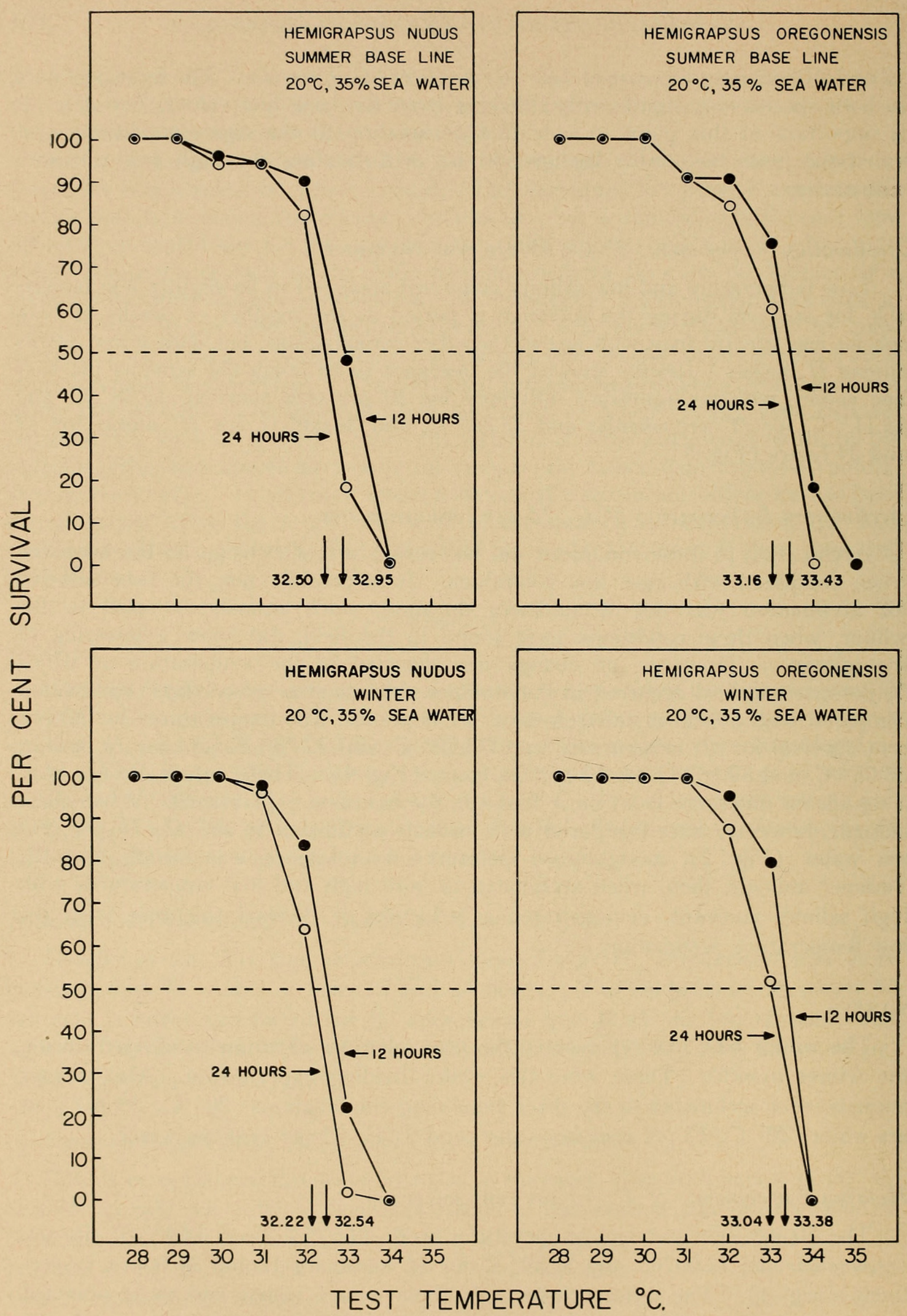

Figure 1. The influence of a previous history of $20^{\circ}$ C., 35 per cent sea water on the 50 per cent survival values at $12(\bullet)$ and $24(\bigcirc)$ hours. Both species in summer and winter are shown. Each point represents the average survival of at least thirty animals. 


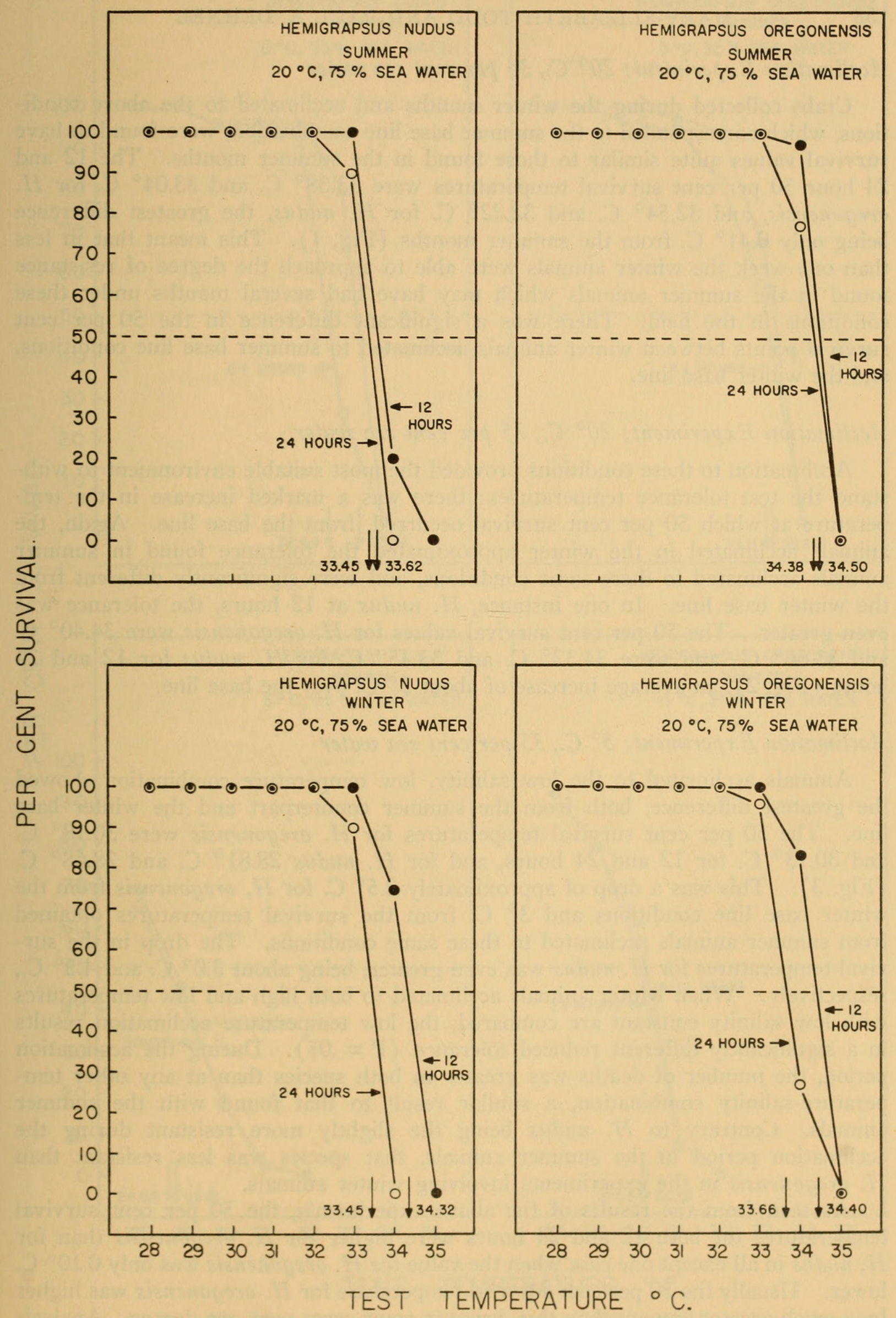

Figure 2. The influence of a previous history of $20^{\circ}$ C., 75 per cent sea water on the 50 per cent survival values at 12 ( ) and $24(\mathrm{O})$ hours. Both species in summer and winter are shown. Each point represents the average survival of at least thirty animals. 


\section{Acclimation Experiment: $20^{\circ}$ C., 35 per cent sea water}

Crabs collected during the winter months and acclimated to the above conditions, which corresponded to the summer base line combination, were found to have survival values quite similar to those found in the summer months. The 12 and 24 hour 50 per cent survival temperatures were $33.38^{\circ} \mathrm{C}$. and $33.04^{\circ} \mathrm{C}$. for $H$. oregonensis, and $32.54^{\circ} \mathrm{C}$. and $32.22^{\circ} \mathrm{C}$. for $H$. nudus, the greatest difference being only $0.41^{\circ} \mathrm{C}$. from the summer months (Fig. 1). This meant that in less than one week the winter animals were able to approach the degree of resistance found in the summer animals which may have had several months under these conditions in the field. There was a significant difference in the 50 per cent survival points between winter animals acclimated to summer base line conditions, and the winter base line.

\section{Acclimation Experiment: $20^{\circ}$ C., 75 per cent sea water}

Acclimation to these conditions provided the most suitable environment to withstand the test tolerance temperatures; there was a marked increase in the temperature at which 50 per cent survival occurred, from the base line. Again, the animals acclimated in the winter approximated the tolerance found in summer animals acclimated to these same conditions, and were significantly different from the winter base line. In one instance, $H$. nudus at 12 hours, the tolerance was even greater. The 50 per cent survival values for $H$. oregonensis were $34.40^{\circ} \mathrm{C}$. and $33.66^{\circ} \mathrm{C}$, and were $34.32^{\circ}$ C. and $33.45^{\circ} \mathrm{C}$. for $H$. mudus for 12 and 24 hours (Fig. 2), an average increase of about $2^{\circ} \mathrm{C}$. over the base line.

\section{Acclimation Experiment: $5^{\circ}$ C., 35 per cent sea water}

Animals acclimated to the low salinity, low temperature combination showed the greatest difference, both from the summer counterpart and the winter base line. The 50 per cent survival temperatures for $H$. oregonensis were $30.18^{\circ} \mathrm{C}$. and $30.13^{\circ} \mathrm{C}$. for 12 and 24 hours, and for $H$. nudus $28.81^{\circ} \mathrm{C}$. and $28.68^{\circ} \mathrm{C}$. (Fig. 3). This was a drop of approximately $2.5^{\circ} \mathrm{C}$. for $H$. oregonensis from the winter base line conditions and $3^{\circ} \mathrm{C}$. from the survival temperatures obtained from summer animals acclimated to these same conditions. The drop in the survival temperatures for $H$. nudus was even greater, being about $3.0^{\circ} \mathrm{C}$. and $4.5^{\circ} \mathrm{C}$., respectively. When winter animals acclimated to both high and low temperatures with low salinity constant are compared, the low temperature acclimation results in a significantly different reduced tolerance $(P=.05)$. During the acclimation period, the number of deaths was greater in both species than at any other temperature-salinity combination, a similar result to that found with the summer animals. Contrary to $H$. nudus being the slightly more resistant during the acclimation period in the summer animals, that species was less resistant than $H$. oregonensis in the experiments involving winter animals.

As seen from the results of the above experiments, the 50 per cent survival temperatures for both 12 and 24 hours were higher for $H$. oregonensis than for $H$. nudus in all except one case when the value for $H$. oregonensis was only $0.10^{\circ} \mathrm{C}$. lower. Usually the 50 per cent survival temperature for $H$. oregonensis was higher by a much greater amount than this, being in some cases over one degree. Analysis 

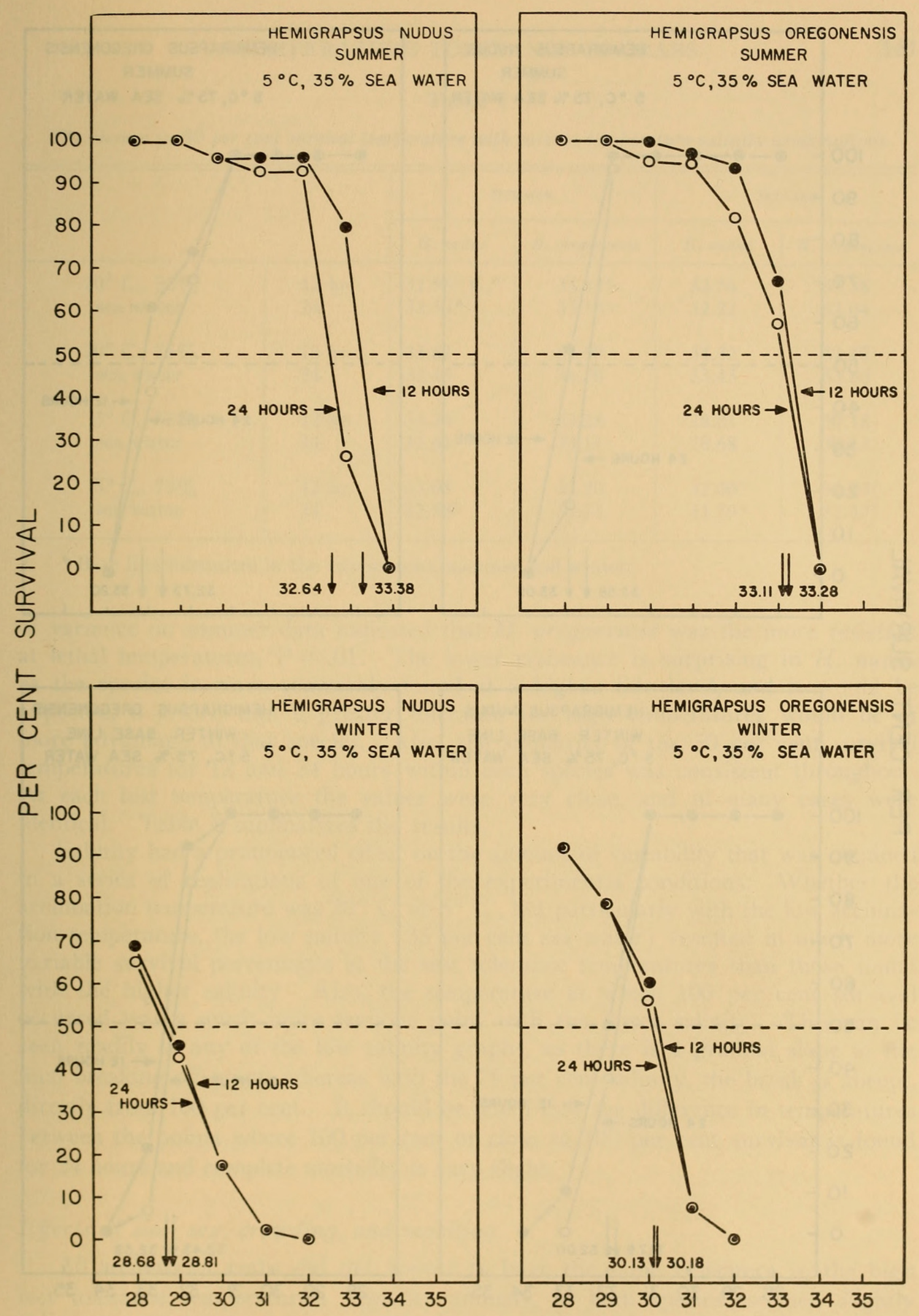

\section{TEST TEMPERATURE ${ }^{\circ} \mathrm{C}$.}

FIGURE 3. The influence of a previous history of $5^{\circ}$ C., 35 per cent sea water on the 50 per cent survival values at 12 ( ) and $24(\bigcirc)$ hours. Both species in summer and winter are shown. Each point represents the average survival of at least thirty animals. 


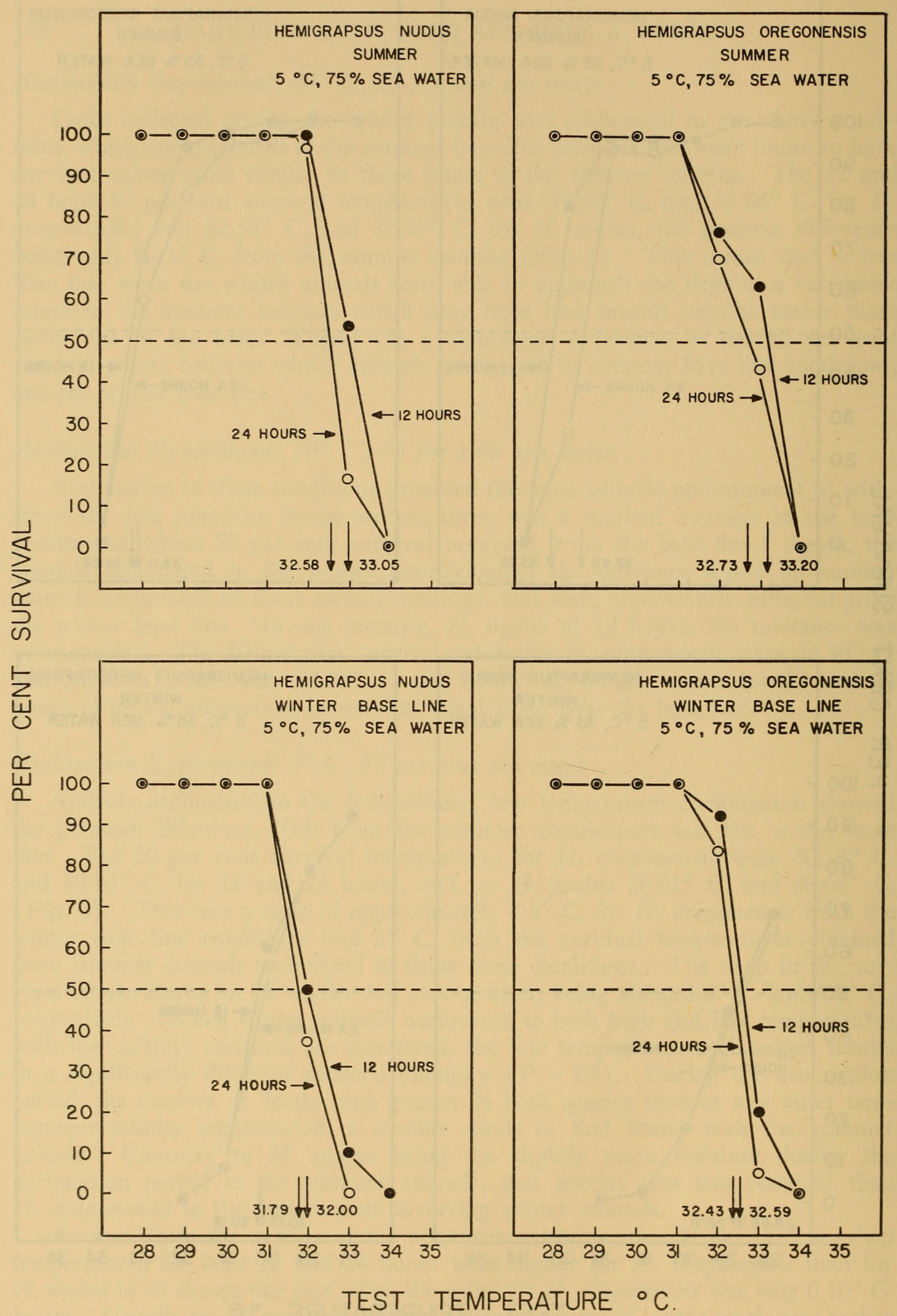

Figure 4. The influence of a previous history of $5^{\circ}$ C., 75 per cent sea water on the 50 per cent survival values at 12 ( ) and $24(O)$ hours. Both species in summer and winter are shown. Each point represents the average survival of at least thirty animals. 
TABLE I

The change in 50 per cent survival temperature with various temperature-salinity combinations

\begin{tabular}{|c|c|c|c|c|c|}
\hline & & \multicolumn{2}{|c|}{ SUMMER } & \multicolumn{2}{|c|}{ WINTER } \\
\hline & & H. nudus & H. oregonensis & H. nudus & H. oregonensis \\
\hline $\begin{array}{c}20^{\circ} \mathrm{C} ., 35 \% \\
\text { sea water }\end{array}$ & $\begin{array}{l}12 \mathrm{hr} . \\
24\end{array}$ & $\begin{array}{l}32.95^{\circ} \mathrm{C} . \\
32.50^{*}\end{array}$ & $\begin{array}{l}33.43^{*} \\
33.16^{*}\end{array}$ & $\begin{array}{l}32.54 \\
32.22\end{array}$ & $\begin{array}{l}33.38 \\
33.04\end{array}$ \\
\hline $\begin{array}{c}20^{\circ} \mathrm{C} ., \quad 75 \% \\
\text { sea water }\end{array}$ & $\begin{array}{l}12 \mathrm{hr} . \\
24\end{array}$ & $\begin{array}{l}33.62 \\
33.45\end{array}$ & $\begin{array}{l}34.50 \\
34.38\end{array}$ & $\begin{array}{l}34.32 \\
33.45\end{array}$ & $\begin{array}{l}34.40 \\
33.66\end{array}$ \\
\hline $\begin{array}{l}5^{\circ} \mathrm{C} ., 35 \% \\
\text { sea water }\end{array}$ & $\begin{array}{l}12 \mathrm{hr} . \\
24\end{array}$ & $\begin{array}{l}33.38 \\
32.64\end{array}$ & $\begin{array}{l}33.28 \\
33.11\end{array}$ & $\begin{array}{l}28.81 \\
28.68\end{array}$ & $\begin{array}{l}30.18 \\
30.13\end{array}$ \\
\hline $\begin{array}{l}5^{\circ} \mathrm{C} ., 75 \% \\
\text { sea water }\end{array}$ & $\begin{array}{l}12 \mathrm{hr} . \\
24\end{array}$ & $\begin{array}{l}33.05 \\
32.58\end{array}$ & $\begin{array}{l}33.20 \\
32.73\end{array}$ & $\begin{array}{l}32.00^{*} \\
31.79^{*}\end{array}$ & $\begin{array}{l}32.59^{*} \\
32.43^{*}\end{array}$ \\
\hline
\end{tabular}

* Base line tolerances in the two seasons, summer and winter.

of variance on summer data indicated that $H$. oregonensis was the more resistant at lethal temperatures, $\mathrm{P}=.01$. The lower resistance is surprising in $H$. nudus as the species is more commonly found at a higher tide level, and it would be expected, a priori, that a greater tolerance for high temperatures would be of more advantage to that species. Also, the similarity of the 50 per cent survival temperatures for 12 and 24 hours within each species was consistent throughout. At each test temperature the values were very close, and in many cases were identical. Table I summarizes the results.

Salinity had a pronounced effect on the amount of variability that was obtained in a series of replications of one of the experimental conditions. Whether the acclimation temperature was $20^{\circ} \mathrm{C}$. or $5^{\circ} \mathrm{C}$., but particularly with the low acclimation temperature, the low salinity (35 per cent sea water) resulted in much more variable survival percentages at the test tolerance temperatures than those found with the higher salinity. Also, the temperature at which 100 per cent survival occurred was a much more tenuous point with the lower salinity. This can be seen readily in any of the low salinity graphs, as there is a gradual slope to the final breaking-off point, whereas with the 75 per cent salinity, the break is abrupt, directly from 100 per cent. It should be noted that the difference in temperatures between the points where 100 per cent or close to 100 per cent survival is found for 24 hours and complete mortality is very slight.

\section{Effects of size, sex, crowding, and moulting}

All weights of crabs did not appear to have the same resistance to the high test tolerance temperatures. Smaller animals, in both species, seemed slightly more tolerant than larger ones. There was no direct relationship between weight and time to death, but results indicated that if any animal lived, it was usually less than 1 gram. This seemingly greater tolerance in the smaller crabs was 


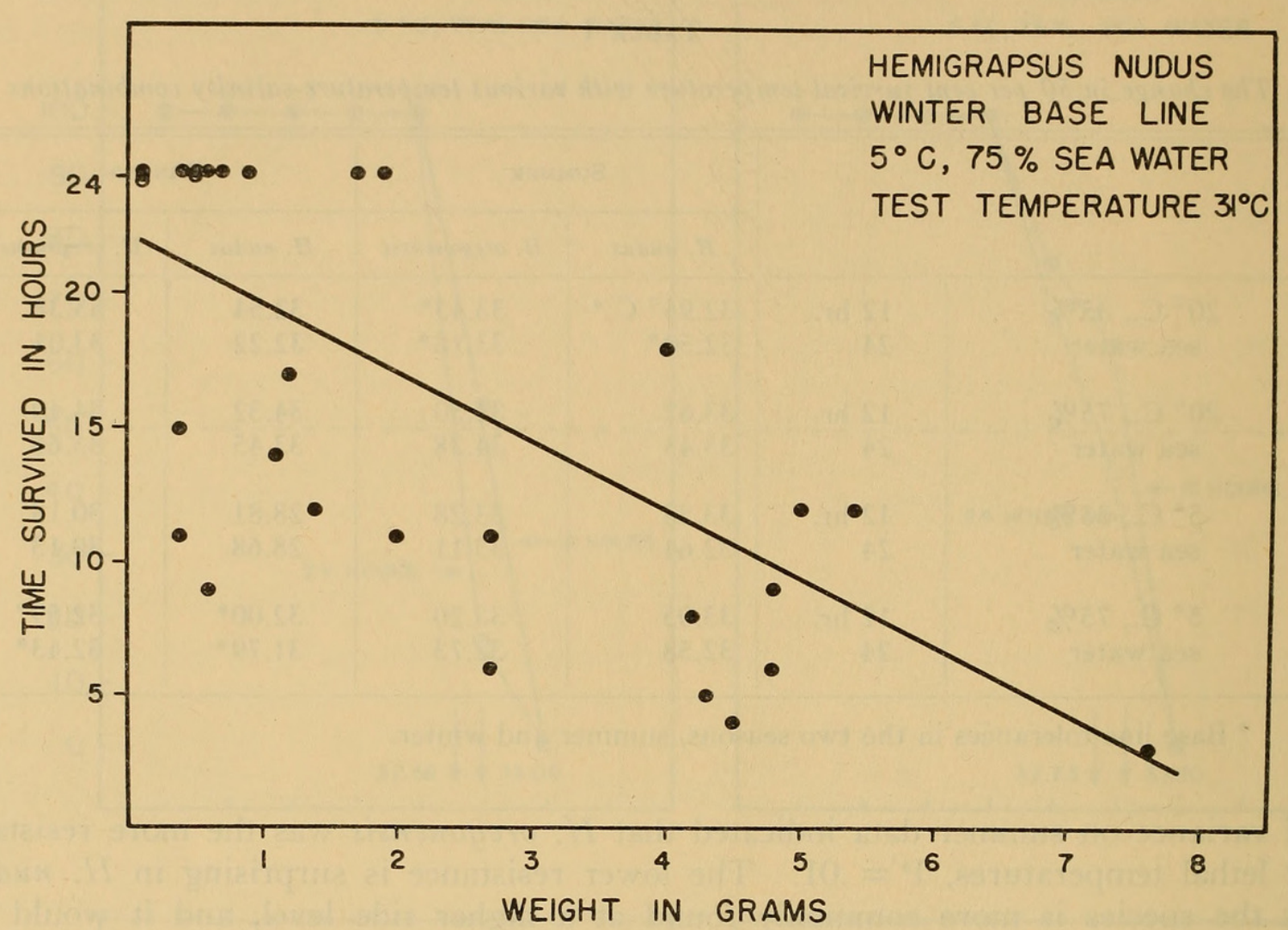

Figure 5. The effect of weight on the time survived in hours at $31^{\circ} \mathrm{C}$. in Hemigrapsus nudus. The animals had a previous history of $5^{\circ} \mathrm{C}$., 75 per cent sea water. Each point represents one animal. The regression line is eye-fitted.

prevalent when crabs from all temperature-salinity combinations were tested. One graph was chosen to demonstrate this phenomenon (Fig. 5).

As mentioned previously, both males and females were used in the experiments when the sex was found to have no influence on the resistance to the high temperatures. To the contrary, crowding, that is more than 5 animals per 4 liters of water, caused a marked lowering of resistance to high temperatures. A minimum value of 0.333 liters of sea water per 1 -gram live animal weight was found to be satisfactory. When less water was allowed, by including more animals per dish, dying animals apparently affected the water even though they were removed immediately upon death, because those remaining were more apt to die (Fig. 6). Thus, with 5 animals per dish, the 50 per cent survival temperature for 12 hours was $32.95^{\circ} \mathrm{C}$., with $10-15$ animals per dish, $30.68^{\circ} \mathrm{C}$., and with $19-28$ animals, $27.86^{\circ} \mathrm{C}$. This crowding effect existed only at the high test tolerance temperatures. As was mentioned in the previous section, when there were at least 35 animals per dish at the acclimation temperature of $20^{\circ} \mathrm{C}$., no mortality due to crowding was noted.

Since only crabs with a fully hardened carapace were used in the experiments, the effects of moulting on the temperature tolerance were determined from those animals which moulted during the 24-hour course of the experiment. These animals invariably died, even at a temperature where 100 per cent survival normally occurred. A possible change in permeability of the carapace after moulting may have rendered the crabs less resistant to high temperatures. 


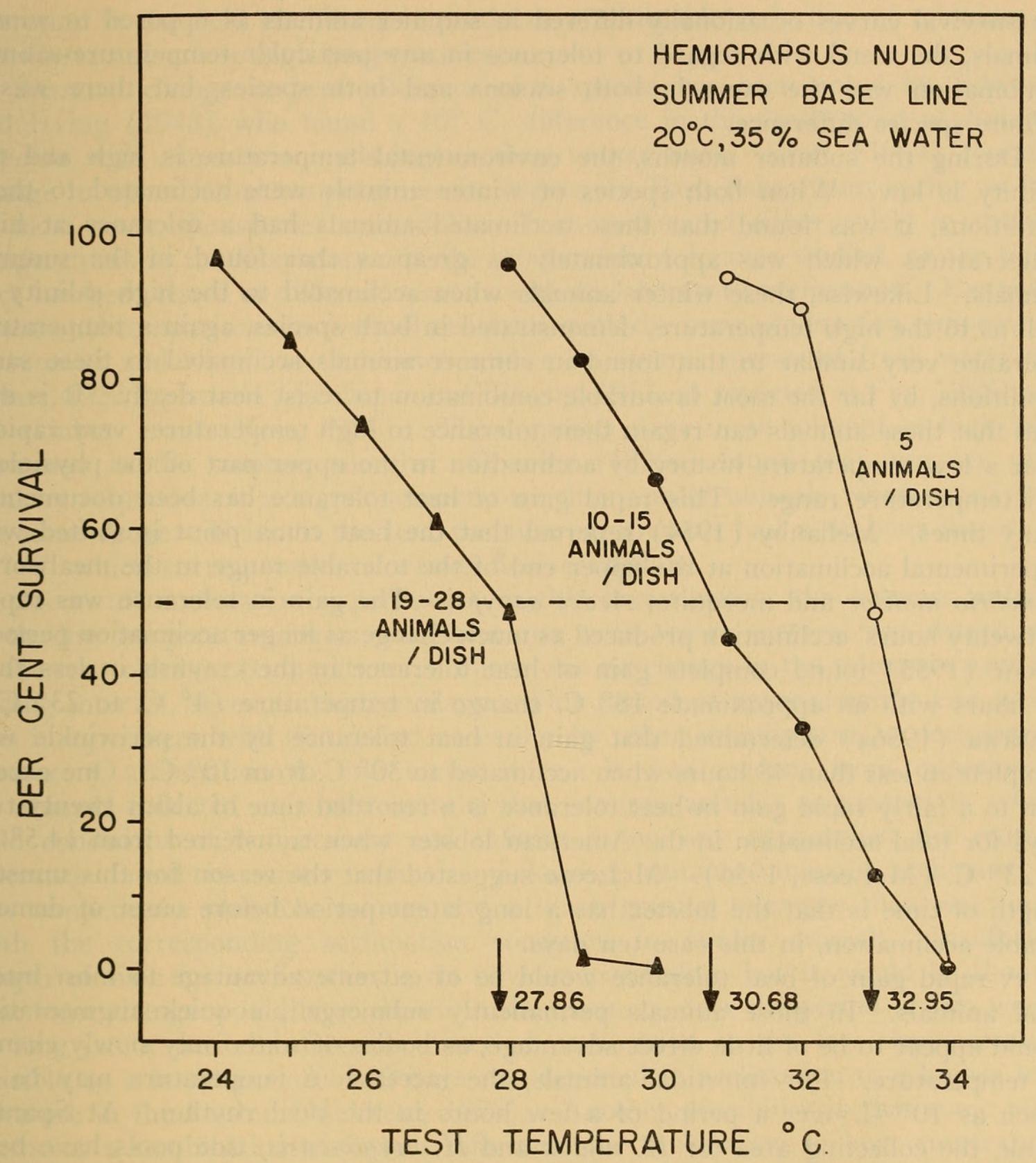

Figure 6. The influence in Hemigrapsus mudus of differing densities of crabs per 4 liters of sea water on the 50 per cent survival temperature at 12 hours with a previous history of $20^{\circ}$ C., 35 per cent sea water: 5 animals per dish ( $\left.\bigcirc\right), 10$ to 15 animals per dish ( ) , 19 to 28 animals per dish ( $)$. Each point represents the average survival of at least thirty animals.

\section{Discussion}

Acclimation to a high temperature, with resulting increase in the high temperature tolerance of the species, has been demonstrated many times (Sumner and Doudoroff, 1938; Brett, 1946; Mellanby, 1954; Spoor, 1955; McLeese, 1956). The two species of crabs, $H$. nudus and $H$. oregonensis, studied here, would seem to be no exception. Temperature tolerance in conjunction with salinity has been studied less extensively, and it was of interest to find that the salinity had a very marked effect on the temperature tolerance of the species. Although results from 
the survival curves occasionally differed in summer animals as opposed to winter animals, the trend with regard to tolerance in any particular temperature-salinity combination was the same in both seasons and both species, but there was a definite species difference.

During the summer months, the environmental temperature is high and the salinity is low. When both species of winter animals were acclimated to these conditions, it was found that these acclimated animals had a tolerance at high temperatures which was approximately as great as that found in the summer animals. Likewise, these winter animals when acclimated to the high salinity as well as to the high temperature, demonstrated in both species, again a temperature tolerance very similar to that found in summer animals acclimated to these same conditions, by far the most favourable combination to resist heat death. It is evident that these animals can regain their tolerance to high temperatures very rapidly after a low temperature history by acclimation in the upper part of the physiological temperature range. This rapid gain of heat tolerance has been documented many times. Mellanby (1954) reported that the heat coma point is shifted with experimental acclimation at the upper end of the tolerable range in the mealworm, Tenebrio molitor and mosquito, Aedes aegypti. The gain in tolerance was rapid, as twenty hours' acclimation produced as much change as longer acclimation periods. Spoor (1955) found complete gain of heat tolerance in the crayfish in less than 24 hours with an approximate $18^{\circ} \mathrm{C}$. change in temperature $\left(4^{\circ} \mathrm{C}\right.$. to $23^{\circ} \mathrm{C}$.) . Ohsawa (1956a) determined that gain in heat tolerance by the periwinkle was complete in less than 48 hours when acclimated to $30^{\circ} \mathrm{C}$. from $10^{\circ} \mathrm{C}$. One exception to a fairly rapid gain in heat tolerance is a recorded time of about twenty-two days for total acclimation in the American lobster when transferred from $14.5^{\circ} \mathrm{C}$. to $23^{\circ}$ C. (McLeese, 1956). McLeese suggested that the reason for this unusual length of time is that the lobster has a long latent period before onset of demonstrable acclimation, in this case ten days.

A rapid gain of heat tolerance would be of extreme advantage to most intertidal animals. In those animals permanently submerged, a quick augmentation would appear to be of little direct advantage, as bodies of water only slowly change in temperature. For intertidal animals, the increase in temperature may be as much as $10^{\circ}$ C. over a period of a few hours in the tidal rhythm. At Spanish Bank, the collecting area for $H$. nudus and $H$. oregonensis, tide pools have been recorded at $26^{\circ} \mathrm{C}$. to $28.5^{\circ} \mathrm{C}$. In this case, a rapid gain in tolerance, particularly over a period of a few hours, would be most advantageous. Probable increase in salinity, due to evaporation in tide pools during the low tide period in summer months, aids the animal in resisting the high temperatures, as experimental results have indicated that high salinity provides the most favourable environment.

Regarding the low temperature series, the results can not be interpreted as readily. The seasonal difference is marked when compared with the difference found in the high temperature series. The change was consistently to a lower temperature for the 50 per cent survival value in the winter animals. For the winter base line, $5^{\circ}$ C., 75 per cent sea water, a drop of about $1^{\circ} \mathrm{C}$., from summer animals acclimated to these same conditions, was found in both species at 12 and 24 hours. With the low salinity, low temperature combination, loss in heat tolerance is much greater. In this low temperature series it is clear that the seasonal 
alteration in the field environment produces a noticeable reduction of tolerance in the winter animals to high temperatures.

Seasonal change in heat tolerance of a species has been noted by Edwards and Irving (1943) who found a $10^{\circ} \mathrm{C}$. difference in the death point of Emerita talpoida with summer animals higher than winter ones. Brett (1944) found a change in upper lethal temperatures in Algonquin Park fishes from spring to fall. In most cases, the species studied have been acclimated either solely to various temperatures in the laboratory and the temperature tolerance studied, or the tolerance has been tested at different seasons with no laboratory acclimation. Examples of seasonal comparisons in thermal resistance with the same acclimation temperature in summer and winter are tolerance studies on several species of fresh water fish (Hart, 1952), planaria (Schlieper and Bläsing, 1953, as reported in Fry, 1958) and the rainbow trout (Keiz, 1953). These species were more tolerant of high temperatures in the summer months. Ohsawa (1956a) found that summer periwinkles responded at a higher temperature than winter animals when tested over the same range. Prior to the test, the summer animals had a 48-hour history at $10^{\circ} \mathrm{C}$. which corresponded to winter field conditions.

As in all acclimation experiments in this investigation, the summer animals of the low temperature series were kept one week before survival was determined at the test tolerance temperatures. There was no change in the tolerance over the testing interval, seven to thirteen days. This period of approximately two weeks was in agreement with that found necessary by other investigators to demonstrate laboratory acclimation to low temperature. It was evident from experiments on animals collected in winter months that summer animals acclimated to winter field conditions of temperature and salinity in no way approached the reduced tolerance found in winter animals. Likewise, summer animals acclimated to low temperature plus low salinity had a much greater tolerance than was found with the corresponding acclimation condition in winter animals. Insufficient length of time for acclimation is an obvious possibility, but it would be thought that some change would have shown in the tolerance over the period of two weeks. A long latent period before the onset of acclimation to the low temperature is feasible, as a latent period of 10 days was reported in acclimation to a higher temperature in the lobster (McLeese, 1956). Another possibility is that some other factor or a combination of factors influences the acclimation to low temperatures but not to the reverse, as winter animals which were acclimated to summer conditions gave approximately the same results as summer animals. Dehnel (1958) has shown in these two species of crabs, $H$. nudus and $H$. oregonensis, that a simulated seasonal variation of light in the laboratory has a pronounced effect on metabolism measured by oxygen consumption. It is feasible that summer animals would never have the same temperature tolerance as that found in the winter animals solely by acclimating them to winter temperature and salinity conditions. Hoar (1956, p. 365) from experiments on goldfish ". . . concluded that the seasonal variations in thermal tolerance previously noted in fish maintained under constant temperature conditions are photoperiodically controlled. ..." It is hoped that future experiments will determine this relationship more clearly in these crabs.

Recently, further experiments were carried out on this problem. There was 
an attempt to acclimate summer crabs of both species to the low salinity, low temperature combination to determine whether results similar to those found in winter could be obtained. This combination was chosen as acclimation to this temperature-salinity condition resulted in greatly reduced tolerances in winter. The summer animals were acclimated for a total of thirty-one days in some experiments. Resistance appeared to be slightly less when compared with tolerances found after shorter periods of acclimation, but was not as low as those found in winter. Also, experiments were done where the animals had an eight-hour photoperiod corresponding to light conditions in winter with the above temperaturesalinity relation. Results again indicated a slightly reduced tolerance but did not appear to differ from those of animals kept in complete darkness. Since two weeks' acclimation in the summer animals did not bring about a change over the testing period, it is important to note that animals cannot be said to acclimate or not acclimate to a parameter merely because there is no evident change.

In nearly all instances low salinity resulted in a lower value for the 50 per cent survival temperature than with high salinity, whether the temperature was $5^{\circ}$ C. or $20^{\circ}$ C. Gross (1957) gives values for $H$. nudus and $H$. oregonensis, calculated from Jones (1941), which indicate the osmotic gradient maintained by these two species when placed in various concentrations of sea water. The crabs are isotonic to the external environment at 100 per cent sea water (based on $34.6 \%$ ). At 75 per cent sea water there is an extremely slight gradient maintained, about 2.5 per cent sea water in $H$. oregonensis and 8.0 per cent in $H$. nudus. The gradient maintained at 35 per cent sea water, however, is about 36 per cent in both species. These values cannot be applied directly to the present experiments, but certainly they can indicate the trend. The maintenance of this gradient presumably results in more work being done by the animal at the lower salinity, and in a greater stress placed on it than at 75 per cent sea water where the gradient is only a few per cent. Additional evidence which suggests more osmotic work is performed at the lower salinity in these crabs is a 22 per cent increase in respiratory rate at 35 per cent over that found at 75 per cent sea water in a 1.0-gram animal measured at $10^{\circ} \mathrm{C}$. (Dehnel, 1960). It is probable that the lower 50 per cent survival temperatures with the lower salinity is due to the increased metabolic work necessary at that salinity. The lethal or near lethal temperatures in the test tolerance experiments presumably alone are causing a marked strain on the metabolic activity of the crabs and the additional strain of maintaining a large gradient between the blood and the external medium in the low salinity results in the animal dying at a lower temperature.

In the present investigation, low salinity, combined with low temperature, particularly in the winter animals, was the most disadvantageous acclimation combination for withstanding the test tolerance temperatures. Wikgren (1953) showed the greater loss of ions with temperature decrease when transferred from tap to distilled water. He thought that this greater loss at the lower temperatures could be assigned to depressed absorption of ions and chloride.

A similar relation between salinity and temperature was found by Broekema (1941) in the shrimp, Crangon crangon. The salinity optimum for length of life depended on the temperature. With a rise in temperature, the salinity optimum was reached by a downward shift in the salinity. High temperatures generally 
were less favourable for survival than low, but low salinity was endured better with a higher temperature. This was similar to the pattern in the two species of crabs studied in these experiments; with low salinity, temperature tolerance was increased when there was a previous high temperature history rather than a low, particularly in winter animals. In addition Broekema showed that the difference between the internal blood concentration and external concentrations in the shrimp was greater at high than at low temperatures and suggested that at low temperatures the limits of life are exceeded sooner than when the temperature is high. Jones (1941) demonstrated a higher osmotic pressure in the blood of $H$. nudus and $H$. oregonensis with a higher temperature, signifying an increase in the degree of regulation. Thus, with a difference in temperature acclimation at the low salinity it is probable that the difference in sustained gradients could carry through to the temperature tolerance tests, and thereby affect the lethal point. Jones, however, showed a great variation in the osmotic pressure of the blood when these crabs were near death from air exposure and felt that this tended to refute a certain lethal osmotic pressure as the primary cause of death.

Broekema's findings, demonstrating that shrimp in a high salinity lived longer at a low temperature, at first appear contrary to the results of this investigation, where the most favourable history for resisting high temperatures was one of both high temperature and high salinity. It must be remembered, however, that the criterion for optimal conditions was quite different, ability to resist lethal temperatures in this investigation, whereas in Broekema's experiments the length of life was the factor. The results cannot be compared directly, but it is felt that they both show the same trend, particularly with respect to low salinities.

Kinne (1958) reported the shifting of heat tolerance in three species of animals, the polychaete Nereis diversicolor, the amphipod Gammarus duebeni, and the isopod Sphaeroma hookeri. The salinity of the pond from which all three species were collected was about $12 \%$, and in all three species when kept at salinities below this, heat resistance is lowered. Increased heat resistance results in animals from the higher salinities, above $12 \%$. Kinne suggested that the alteration of water and ion balance resulting in increased water content at extremely low salinities decreases the heat tolerance; the lowered water content at higher salinities favourably affects the resistance to high temperatures. The range of test salinities was beyond the limits of regulation in Gammarus duebeni from values given by Verwey (1957) and at the upper salinities in Nereis diversicolor (Smith, 1955b). Another explanation than alteration of water content may be necessary when similar changes in tolerance occur over the physiological regulatory range where variation is slight. Since the salinity of the pond where the animals were collected was only $12 \%$, this would result in a fairly large sustained gradient at least in two of the three species for which data are available. The salinities could cause increased susceptibility to lethal temperatures. The higher salinities presumably within limits would approximate more nearly natural conditions in the body fluids of the animals, to provide a more favourable environment for survival. Another species studied by Kinne (1956), the hydroid Cordylophora caspia, has slight osmoregulatory abilities, and again was found to withstand a high temperature better at a high salinity than at lower ones. Possibly the explanation here could be that the higher salinity is nearer the concentration of body fluids of the hydroid, 
resulting in a more favourable environment to resist a stress, in this case, high temperature.

The geographic limitation of the polychaete Nereis is related to the salinitytemperature balance of its environment. The range of Nereis diversicolor in the Baltic Sea apparently is limited by the colder parts of the year when it could not withstand the low salinity expressed as a chlorinity of 4 grams per liter in which it is able to regulate adequately in the warmer summer months (Smith, 1955a). Studies on Neanthes lighti indicated that it was able to survive in fresh water in Lake Merced, California, because of its viviparous mode of reproduction where the young are sufficiently developed at birth that they are able to osmoregulate, and that the species is not exposed to severe winter cold. Laboratory experiments showed that the ability to regulate in water of a chlorinity of 1.0 to 0.09 grams per liter was inhibited at $1.5^{\circ} \mathrm{C}$. but possible at $13^{\circ} \mathrm{C}$. in worms tested in vitro (Smith, 1957).

Animals acclimated to temperatures in the upper part of their physiological temperature range show a remarkable similarity in lethal temperatures. A few comparisons for estimated 12 hours median tolerance among animals acclimated to approximately $20^{\circ} \mathrm{C}$. and a favourable salinity, if marine forms, are given in Table II. For the most part the lethal temperature is at least $30^{\circ} \mathrm{C}$. In the species difference found in this investigation, the greater thermal resistance of $H$. oregonensis is surprising since it occupies a lower level on the beach. Within the same species, Littorina litorea, the individuals collected at high tide level had greater resistance to lethal temperatures than those collected a few yards away at low tide level (Gowanloch and Hayes, 1926). Ohsawa (1956b) determined species difference for the periwinkles Nodilittorina granularis and $N$. vilis. The latter occurs in the upper zone of the wide range occupied by $N$. granularis, which was found to be the more tolerant at lethal temperatures, a similar result to that found with $H$. nudus and $H$. oregonensis.

In most animals, then, and possibly all, a previous high temperature history increases heat tolerance and a low one decreases it. Along with this is the influence of salinity where low salinities almost invariably are endured better at a higher temperature, and high temperature, high salinity combined being most favourable for withstanding upper lethal temperatures. Low salinity, low temperature generally is least favourable for length of life and for heat tolerance (Fig. 7).

TABLE II

A comparison of tolerances to high temperature in several species

Species

Hemigrapsus nudus

$H$. oregonensis

Orconectes rusticus

O. propinquus

Cambarus fodiens

Homarus americanus

Hyalella azteca

Ameiurus nebulosus

Carassius auratus
12 hour median tolerance,

33.62

34.50

36.4

35.0

35.0

28.4-30.5

33.0

33.4

34.5
Source

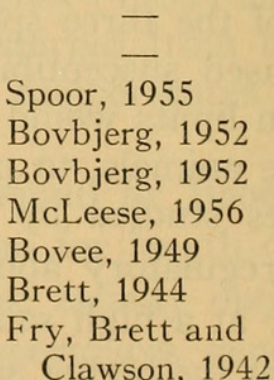




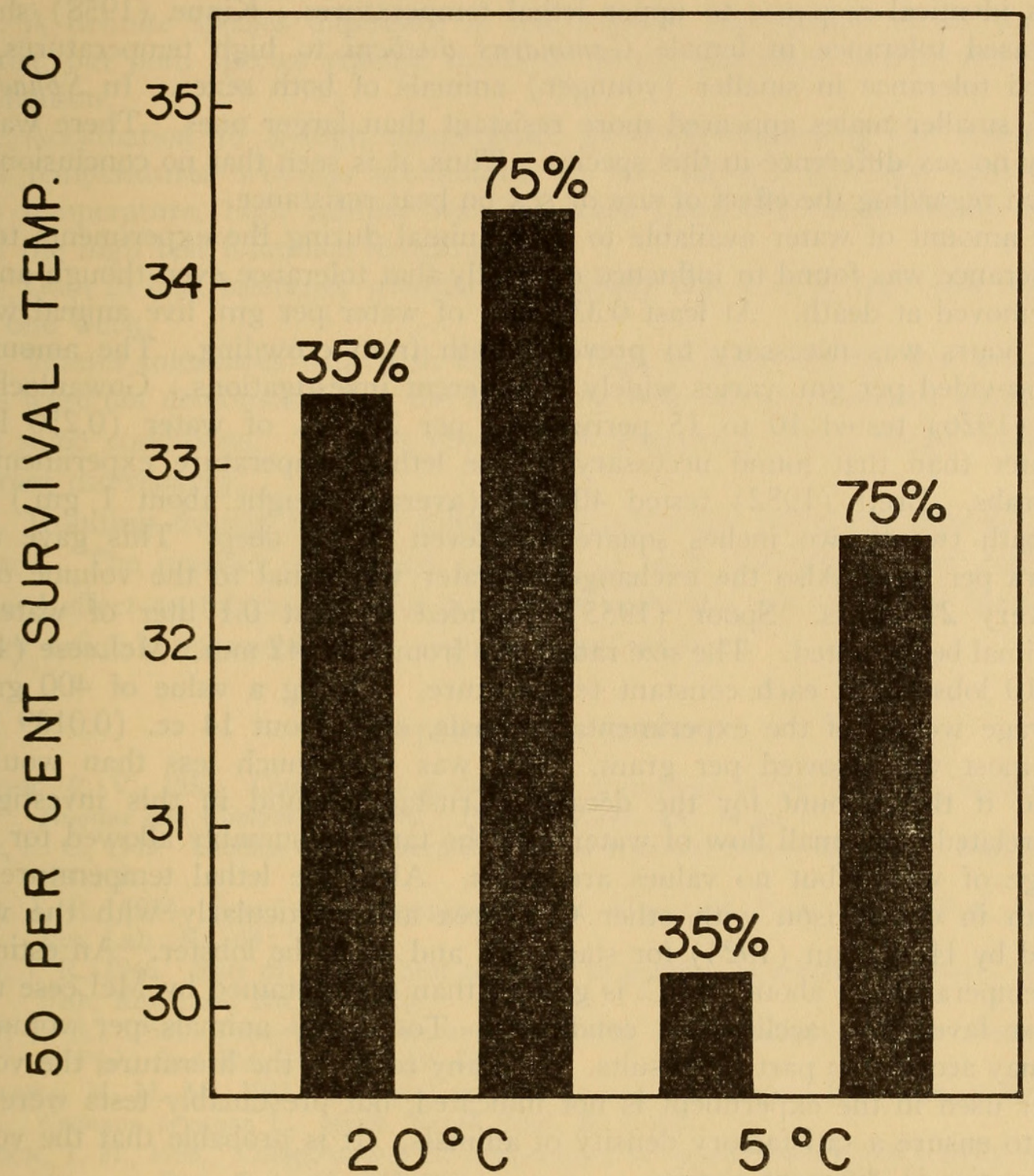

Figure 7. Median tolerance temperatures for Hemigrapsus oregonensis for 12 hours with previous histories of $20^{\circ}$ C. or $5^{\circ}$ C. and 35 per cent or 75 per cent sea water. Animals were collected in winter.

The effect of size and sex on heat tolerance was found to vary in different animals reported in the literature. In $H$. nudus and $H$. oregonensis, smaller animals seemed to be slightly more resistant to the high test tolerance temperatures than larger individuals. There was no difference in tolerance between the sexes. Edwards and Irving (1943) found no difference in tolerance in Emerita talpoida between males and females, but larger animals seemed slightly more resistant than small ones. In lethal temperature experiments on young speckled trout, Salvelinus fontinalis, size did not affect time to death at high temperatures in the same age group (Fry, Hart and Walker, 1946). Hoar (1955) found an increased tolerance at $1^{\circ}-2^{\circ} \mathrm{C}$. in goldfish with an increase in size from 3 to $7.5 \mathrm{~cm}$. In the crayfish, sex and size did not affect heat tolerance (Spoor, 1955). McLeese (1956) concluded that in the size range of lobsters studied, from 21 to $28 \mathrm{~cm}$., 
there is identical response to upper lethal temperatures. Kinne (1958) showed a decreased tolerance in female Gammarus duebeni to high temperatures, and increased tolerance in smaller (younger) animals of both sexes. In Sphaeroma hookeri, smaller males appeared more resistant than larger ones. There was apparently no sex difference in this species. Thus, it is seen that no conclusions can be drawn regarding the effect of size or sex on heat resistance.

The amount of water available to each animal during the experiments testing heat tolerance was found to influence markedly that tolerance even though animals were removed at death. At least 0.333 liter of water per gm. live animal weight per 12 hours was necessary to prevent death from crowding. The amount of water provided per gm. varies widely in different investigations. Gowanloch and Hayes (1926) tested 10 to 15 periwinkles per $250 \mathrm{cc}$. of water (0.250 liter), less water than that found necessary in the lethal temperature experiments on these crabs. Brett (1952) tested 40 fish (average weight about $1 \mathrm{gm}$.) in a lethal bath twenty-two inches square by eleven inches deep. This gave about 2.2 liters per gm. Also the exchange of water was equal to the volume of the tank every 24 hours. Spoor (1955) provided at least 0.1 liter of water for each animal being tested. The size range was from 17 to $42 \mathrm{~mm}$. McLeese (1956) tested 10 lobsters at each constant temperature. Taking a value of $400 \mathrm{gm}$. as an average weight of the experimental animals, only about $14 \mathrm{cc}$. (0.0139 liter) at the most was allowed per gram. This was very much less than would be expected if the amount for the decapod Crustacea found in this investigation can be related. A small flow of water into the tank presumably allowed for some exchange of water, but no values are given. Also, the lethal temperatures are low both in comparison with other Crustacea and particularly with the values obtained by Huntsman (1924) for stages IV and V in the lobster. An estimated lethal temperature of about $34^{\circ} \mathrm{C}$. is greater than that obtained by McLeese under the most favourable acclimation conditions. Too many animals per volume of water may account in part for results. In many cases in the literature, the volume of water used in the experiment is not indicated, but presumably tests were conducted to ensure a satisfactory density of animals. It is probable that the volume needed varies in different species.

Moulting during the 24 hours of the experiment was found to have an adverse effect on high temperature tolerance in $H$. nudus and $H$. oregonensis. Crayfish moulted successfully in temperatures from $12^{\circ}$ C. to $36^{\circ} \mathrm{C}$.; the stage in the moult cycle had no effect upon heat tolerance (Spoor, 1955). To the contrary, McLeese (1956) showed that the average survival time for soft-shell lobsters was less than that for hard-shelled individuals. As results from various workers differ, nothing definite can be concluded about a relationship between moulting and death at high lethal temperatures.

\section{SUMMARY}

1. The influence on heat tolerance was determined of seasonal change and laboratory acclimation to various temperature-salinity combinations, for two species of grapsoid crabs, Hemigrapsus nudus and $H$. oregonensis.

2. There was a seasonal change in 50 per cent survival in both species when base lines from summer and winter were compared. 
3. A definite species difference in tolerance to high temperatures was found to exist, but both species reacted similarly to any particular temperature-salinity combination.

4. Acclimation to a high temperature generally increased the resistance to lethal temperatures whereas acclimation to low salinity generally decreased it. High temperature, high salinity was the most favourable combination to withstand the high test tolerance temperatures.

5. Gain in heat tolerance whether the salinity was low or high was rapid, less than one week.

6. Winter tolerances with both low and high salinities in the low temperature series were not demonstrated in the laboratory with summer animals acclimated to these same conditions. Various reasons are suggested which might explain this apparent discrepancy.

7. Moulting during the test tolerance experiments adversely affected the resistance. The number of animals per dish at each test temperature had a pronounced effect on tolerance. The sex of the crabs did not affect the survival, but smaller animals appeared to be slightly more resistant.

\section{LITERATURE CITED}

BovBJerg, R. V., 1952. Comparative ecology and physiology of the crayfish Orconectes propinquus and Cambarus fodiens. Physiol. Zoöl., 25: 34-56.

Bovee, E. C., 1949. Studies on the thermal death of Hyalella azteca Saussure. Biol. Bull., 96 : 123-128.

Brett, J. R., 1944. Some lethal temperatures of Algonquin Park fishes. Pub. Ont. Fish. Res. Lab., No. 63 : 5-49.

BREtT, J. R., 1946. Rate of gain of heat tolerance in goldfish (Carassius auratus). Pub. Ont. Fish. Res. Lab., No. 64: 5-28.

Brett, J. R., 1952. Temperature tolerance in young Pacific salmon, Genus Oncorhynchus. J. Fish. Res. Bd. Can., 9: 265-323.

Broekema, M. M. M., 1941. Seasonal movements and the osmotic behaviour of the shrimp, Crangon crangon L. Arch. Néerl. Zool., 6: 1-100.

Bullock, T. H., 1955. Compensation for temperature in the metabolism and activity of poikilotherms. Biol. Rev., 30: 311-342.

Dennel, P. A., 1955. Rates of growth of gastropods as a function of latitude. Physiol. Zoöl., 28: $115-144$.

Dehnel, P. A., 1958. Effect of photoperiod on the oxygen consumption of two species of intertidal crabs. Nature, 181: 1415-1417.

Dennel, P. A., 1960. Effect of temperature and salinity on the oxygen consumption of two species of intertidal crabs. Biol. Bull., 118 (in press).

Dehnel, P. A., and E. Segal, 1956. Acclimation of oxygen consumption to temperature in the American cockroach (Periplaneta americana). Biol. Bull., 111: 53-61.

Edwards, G. A., And L. Irving, 1943. The influence of temperature and season upon the oxygen consumption of the sand crab, Emerita talpoida Say. J. Cell. Comp. Physiol., 21: 169-182.

Fry, F. E. J., 1958. Temperature compensation. Ann. Rev. Physiol., 20: 207-224.

Fry, F. E. J., J. R. Brett and G. H. Clawson, 1942. Lethal limits of temperature for young goldfish. Rev. Can. de Biol., 1: 50-56.

Fry, F. E. J., J. S. Hart And K. F. Walker, 1946. Lethal temperature relations for a sample of young speckled trout, Salvelinus fontinalis. Pub. Ont. Fish. Res. Lab., No. 66: 9-35.

Gowanloch, J. N., and F. R. Hayes, 1926. Contributions to the study of marine gastropods. I. The physical factors, behaviour and intertidal life of Littorina. Contr. Can. Biol., N.S., 3: 135-165. 
Gross, W. J., 1957. An analysis of response to osmotic stress in selected decapod crustacea. Biol. Bull., 112: 43-62.

HART, J. S., 1952. Geographic variations of some physiological and morphological characters in certain freshwater fish. Pub. Ont. Fish. Res. Lab., No. 72: 1-79.

HoAr, W. S., 1956. Photoperiodism and thermal resistance in goldfish. Nature, 178: 364-365.

Huntsman, A. G., 1924. Limiting factors for marine animals. 2. Resistance of larval lobsters to extremes of temperature. Contr. Can. Biol., N.S., 2: 89-93.

Huntsman, A. G., and M. I. Sparks, 1924. Limiting factors for marine animals. 3. Relative resistance to high temperatures. Contr. Can. Biol., N.S., 2: 95-114.

Jones, L. L., 1941. Osmotic regulation in several crabs of the Pacific Coast of North America. J. Cell. Comp. Physiol., 18: 79-92.

KeIz, G., 1953. Über die Beziehungen zwischen Temperatur-Akklimatisation und Hitzeresistenz bei eurythermen und stenothermen Fischarten (Squalius cephalus L. und Trutta iridea W. Gibb). Naturwiss., $40: 245-250$.

Kinne, O., 1956. Über den Einfluss des Salsgehaltes und der Temperatur auf Wachstum, Form und Vermehrung bei dem Hydroidpolypen Cordylophora caspia (Pallas), Thecata, Clavidae. Zool. Jahrb., Allg. Zool. u. Phys., 66: 565-638.

Kinne, O., 1958. Adaptations to salinity variations-some facts and problems. Reprinted from Physiological Adaptations (Amer. Physiol. Soc., Wash., D. C.), 92-106.

Mayer, A. G., 1914. The effects of temperature upon tropical marine animals. Pap. Tortugas Lab., 6: 3-24.

Mellanby, K., 1954. Acclimatization and the thermal death points in insects. Nature, 173: 582.

McLeese, D. W., 1956. Effects of temperature, salinity, and oxygen on the survival of the American lobster. J. Fish. Res. Bd. Can., 13: 247-272.

Ohsawa, W., 1956a. The experimental acclimatization in the temperature response relation and the heat tolerance of the periwinkle, Nodilittorina gramularis (Gray). J. Inst. Polytechnics, Ser. D, $7:$ 197-217.

Ohsawa, W., 1956b. The species difference in the concentration and temperature response relations and the heat tolerance of periwinkles. J. Inst. Polytechnics, Ser. D, $7: 219-227$.

Ohsawa, W., and H. Tsukuda, 1956. The seasonal variation in the temperature response relation and temperature tolerance of the periwinkle, Nodilittorina gramularis (Gray). J. Inst. Polytechnics, Ser. D, 7: 173-188.

Scholander, P. F., W. Flagg, V. Walters and L. Irving, 1953. Climatic adaption in Arctic and tropic poikilotherms. Physiol. Zoöl., 26: 67-92.

SEGAL, E., 1956. Microgeographic variation as thermal acclimation in an intertidal mollusc. Biol. Bull., 111: 129-152.

Smith, R. I., 1955a. On the distribution of Nereis diversicolor in relation to salinity in the vicinity of Tvärminne, Finland, and the Isefjord, Denmark. Biol. Bull., 108: 326-345.

Sмith, R. I., 1955b. Comparison of the level of chloride regulation by Nereis diversicolor in different parts of its geographical range. Biol. Bull., 109: 453-474.

Sмith, R. I., 1957. A note on the tolerance of low salinities by nereid polychaetes and its relation to temperature and reproductive habit. Ann. Biol., 33: 93-107.

Spoor, W. A., 1955. Loss and gain of heat tolerance by the crayfish. Biol. Bull., 108: 77-87.

Sumner, F. B., And P. Doudoroff, 1938. Some experiments on the temperature acclimatization and respiratory metabolism in fishes. Biol. Bull., 74: 403-429.

Verwey, J., 1957. A plea for the study of temperature influence on osmotic regulation. Ann. Biol., 33 : 129-149.

Wikgren, B., 1953. Osmotic regulation in some aquatic animals with special reference to the influence of temperature. Acta Zool. Fennica, 71: 1-102. 


\section{$2 \mathrm{BHL}$ Biodiversity Heritage Library}

Todd, Mary-Elizabeth and Dehnel, Paul A. 1960. "Effect of temperature and salinity on heat tolerance in two grapsoid crabs, Hemigrapsus nudus and Hemigrapsus oregonensis." The Biological bulletin 118, 150-172. https://doi.org/10.2307/1539065.

View This Item Online: https://www.biodiversitylibrary.org/item/110976

DOI: https://doi.org/10.2307/1539065

Permalink: https://www.biodiversitylibrary.org/partpdf/2130

\section{Holding Institution}

Smithsonian Libraries

\section{Sponsored by}

Biodiversity Heritage Library

\section{Copyright \& Reuse}

Copyright Status: In copyright. Digitized with the permission of the rights holder.

License: http://creativecommons.org/licenses/by-nc-sa/3.0/

Rights: https://biodiversitylibrary.org/permissions

This document was created from content at the Biodiversity Heritage Library, the world's largest open access digital library for biodiversity literature and archives. Visit BHL at https://www.biodiversitylibrary.org. 